\title{
Physico-chemical characteristics and therapeutic potential of Chutrun thermal springs in Shigar Valley, Gilgit-Baltistan (Pakistan)
}

\author{
Naima Farhat $^{1} \cdot$ Shabbir Hussain $^{1}\left[\cdot\right.$ Foqia Faisal $^{2} \cdot$ Iqra Batool $^{1} \cdot$ Mafia Noreen $^{1}$
}

Received: 23 July 2020 / Accepted: 23 December 2020 / Published online: 14 January 2021

(c) The Author(s) 2021

\begin{abstract}
Current studies were performed to evaluate the physico-chemical characteristics and therapeutic potential of Chutrun thermal springs located in the North-west of Shigar Valley, Gilgit-Baltistan (Pakistan). Thermal springs with different mineral contents have been used by people for bathing and health purposes since old timings. The mineral water of these springs contains elements like sodium, potassium, calcium, magnesium as chlorides, fluorides, sulphates, phosphates and bicarbonates which may be responsible for cure of various diseases. Chutrun hot springs have $7.21-7.8 \mathrm{pH}, 40-42^{\circ} \mathrm{C}$ Temperature, $300-310 \mathrm{ppm}$ TDS, 3.1-6.7 ppm DO, 278-285 ppm hardness, 1.62-2.42 ppm turbidity, 250-260 ppm alkalinity, 500-516 ppm conductivity, 12-18 ppm sodium, 3.8-4.1 ppm potassium, 80-82 ppm calcium, 20 ppm magnesium, 9.6-12 ppm chlorides, 3.4-3.9 fluorides, 260-282 bicarbonates and 80-85 ppm sulphates. Absence of E.Coli and faecal coliforms indicated that waters from thermal springs are free from organic wastes contaminations. Water from thermal springs of Chutrun was unsuitable for drinking purposes due to the presence of high fluoride content and also small amount of total coliforms which may be due to the presence of environmental bacteria and non-protective measures during sampling but it was found suitable for bathing and other body contact activities.
\end{abstract}

Keywords Thermal springs $\cdot$ Shigar $\cdot$ Physico-chemical $\cdot$ Therapeutic

\section{Introduction}

Hot groundwater containing an elevated temperature rises from the earth surface for the production of thermal springs. Usually, these thermal springs arise from fissure of earth crust and its deep faults. The main reasons for high temperature of thermal springs are exothermic reactions, geothermal energy and disintegration reactions of radioactive elements. The geothermal waters are rich in dissolved solids and various minerals like alkali metals, alkaline earth metals, carbonates, bicarbonates, sulphates, trace elements and gases (Bisht et al. 2011; Mohanty et al. 2014).

According to reports, water from thermal springs contains some rectifying effects for the treatment of various diseases, e.g., atopic dermatitis, cardiovascular diseases,

Shabbir Hussain

dr.shabbirhussain@1gu.edu.pk; shabchem786@gmail.com

1 Department of Chemistry, Lahore Garrison University, Lahore, Pakistan

2 National Water Quality Laboratory (NWQL), PCRWR, Ministry of Science and Technology, Islamabad, Pakistan inflammatory arthritis, ankylosing spondylitis, rheumatic disease, asthma and rhino sinusitis. Moreover, it is commonly believed that soaking in hot spring helps to treat joint pains and strained muscles (Lele and Deshmukh 2016; Liang et al. 2015). Absorption of minerals through soaking is fractional, and the amount absorbed into the body is concentration dependent (Lopez et al. 2002).

There are 7000 enzymatic processes involved in human body metabolism which requires minerals and trace elements, out of which over 80 essential nutrients and minerals are found in hot mineral water. Balneology, the practice of using thermal/hot mineral water for the treatment and cure of diseases, also has a long history (Luime et al. 2004). Absorption of minerals through soaking in hot springs is trivial and it depends upon concentration of minerals in hot/ thermal springs. It varies depending upon the minerals and its chemical form in hot springs (Javed et al. 2009).

Animals are believed to discover the medicinal properties of thermal springs through curing their feet, wounds, or maintaining their body temperature. Afterwards, mankind began to explore the therapeutic properties of hot springs. Medical hydrology is today a modern branch of medicine. 
In 1986, thermal springs were declared as an alternative source of treatment to get good physical and mental health. Thus emerging as a new discipline, medical hydrology has been accepted as complementary medicine by World Health Organization (Reyes et al. 2015). Thermal springs are natural sources which, if probed optimally, have the potential to make considerable contribution in certain pragmatic ways. However, some studies have suggested that geothermal water may contain toxic elements such as arsenic and mercury, hence care should be exercised regarding appropriate and precise use of thermal springs (Olivier et al. 2008).

Current studies were performed to investigate the physico-chemical characteristics and therapeutic potential of Chutrun Thermal Springs in Shigar Valley, Gilgit-Baltistan (Pakistan) as these springs have been used by the people for the cure of many diseases since from the long times.

\section{Materials and methods}

\section{Study area}

Chutrun Thermal Springs in Shigar Valley were subjected to physico-chemical and therapeutic investigations. Shigar Valley is located in Northern part of Pakistan. In the north-western suburbs of Shigar Valley at a distance of approx. $46 \mathrm{kms}$, lies Union Council of Tisar having an approximate population of 450-500 members. Tisar is famously referred to as Chutrun, owing to the hot water springs located in the village. Chutrun is a combination of two words of native language "Chu" meaning "water" and "trun" meaning "hot". Chutrun comprises of four different springs located within an area of approximately $100 \mathrm{~m}$. Figures 1 and 2 represent the pictorial view of both the thermal springs.

\section{Chutrun latitude and longitude}

Latitude $($ DMS $)=36^{\circ} 40^{\prime} 33^{\prime \prime} \mathrm{N}$; Longitude $($ DMS $)=75^{\circ}$ $26^{\prime 2} 26^{\prime \prime} \mathrm{E}$; UTM Zone $=43 \mathrm{~S}$

Elevation $=8023 \mathrm{Ft}$

The area with harsh and lofty mountains typically represents the Karakorum Range. It also maps the Baltoro Glacier which is largest out of arctic regions being $56 \mathrm{Kms}$ long which peculiarly defines the weather of the area of study (Agheem et al. 2011, 2004; Blauwet et al. 1997).

\section{Sampling}

Water samples were collected from four thermal springs of Chutrun in polyethene screw capped bottles in March 2018. The sample bottles were washed with tap water followed by rinsing with distilled water before collecting the samples. All precautions were taken during sampling, transportation and storage.

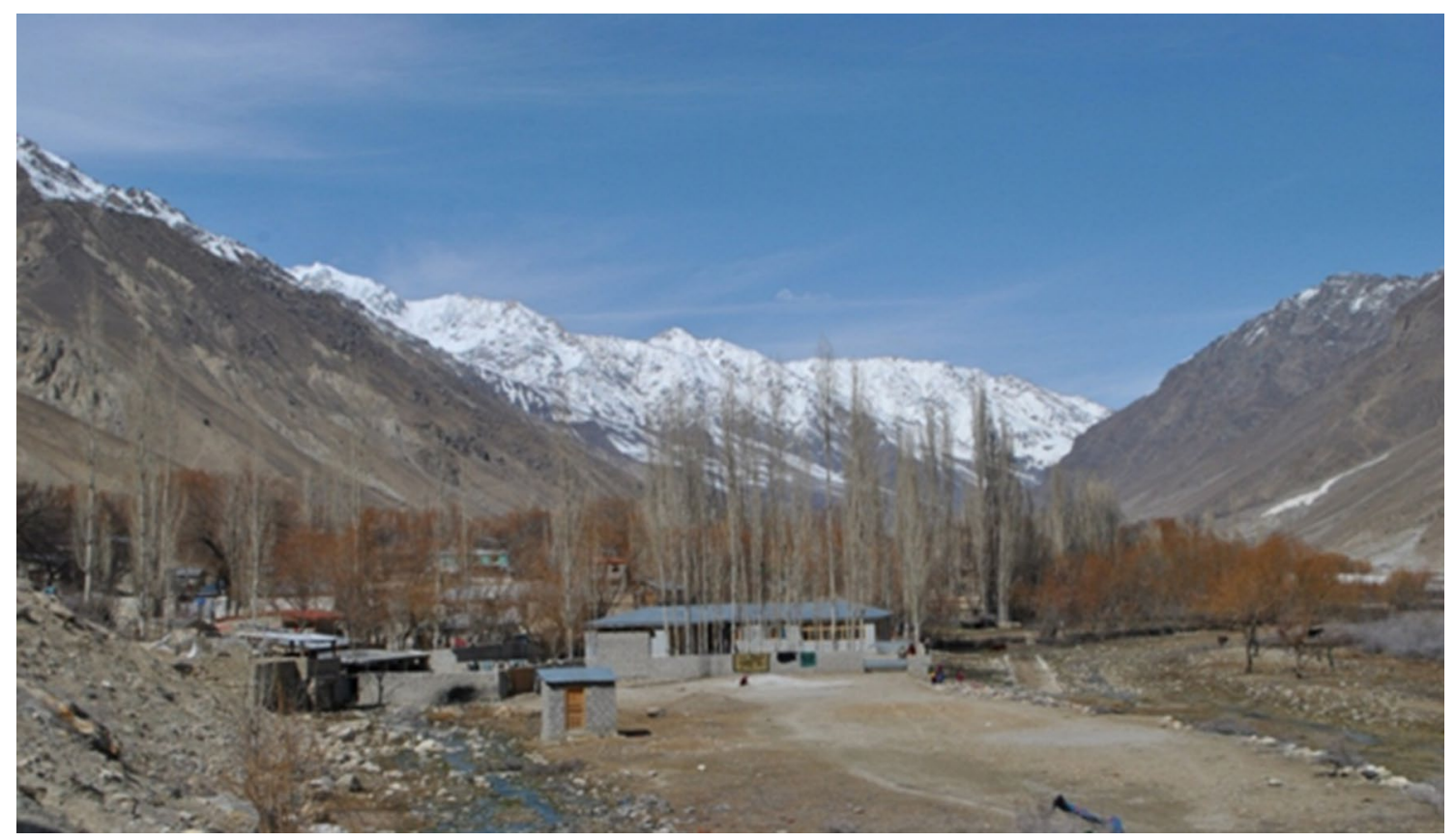

Fig. 1 Chutrun Hot Springs, Shigar Valley, Gilgit-Baltistan 

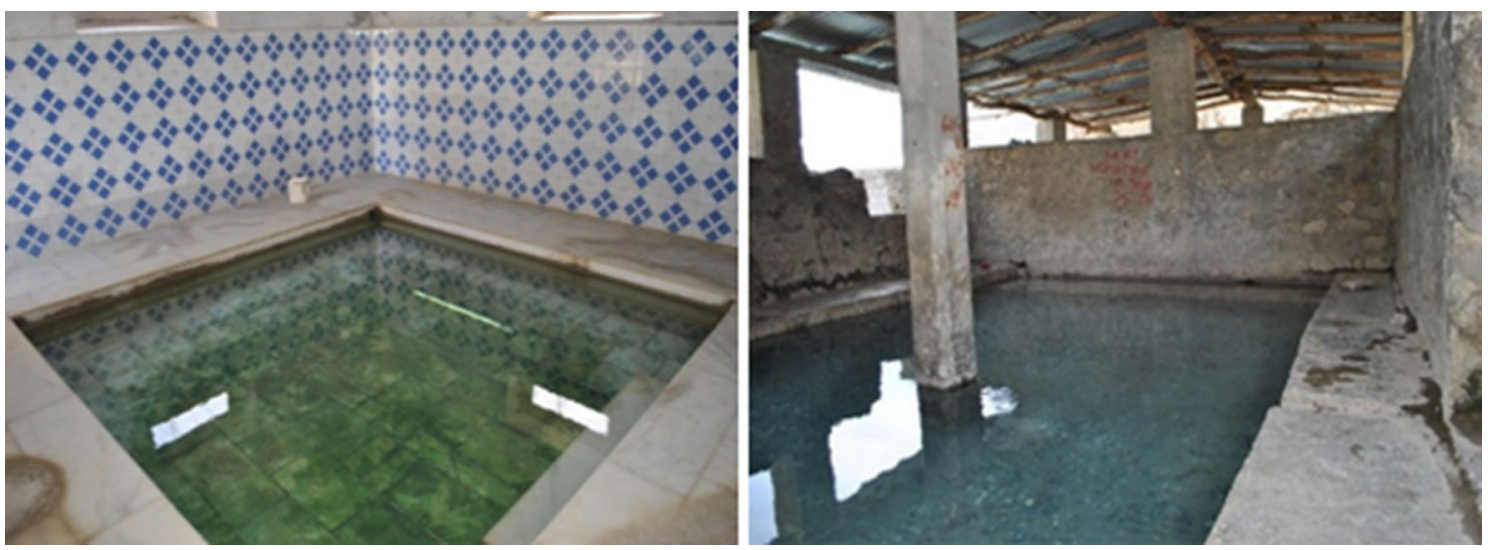

Fig. 2 Bathing area
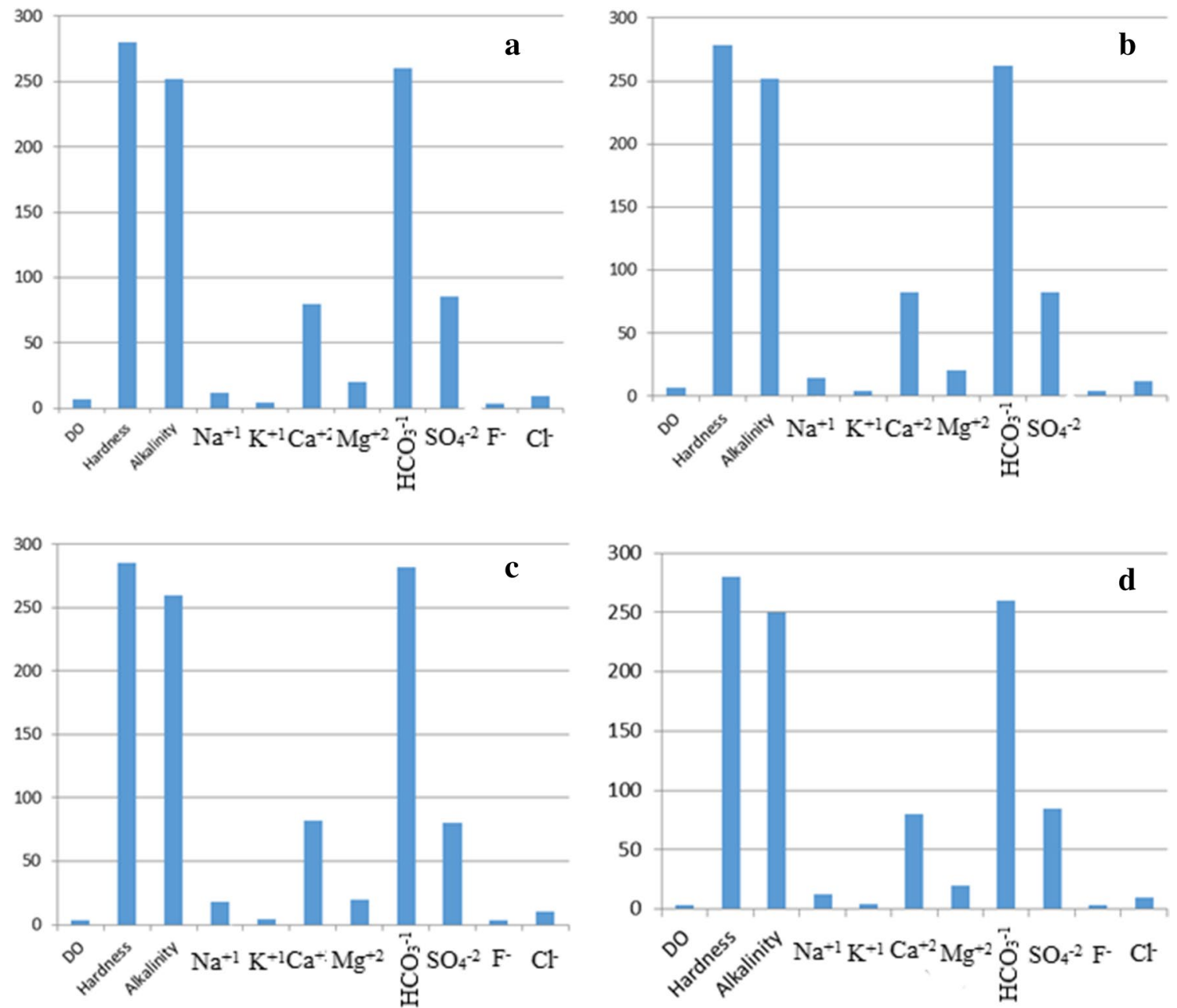

Figures 3 a-d: Graphical-representation of some important physico-chemical parameters of Chutrun Thermal Spring 1 (a), Spring 2 (b), Spring 3 (c) and Spring 4 (d)

\section{Analysis}

Temperature of each sample was measured at the time of its collection. Calibrated instruments were used to measure $\mathrm{pH}$ (HANNA pH210), Conductivity, TDS (JENWAY 4320) and Turbidity (HANNA HI 93,703). Titration methods were used 
to measure the alkalinity, bicarbonate (acidimetric), chlorides (argentometric), calcium and magnesium (complexometric). Sodium and potassium were measured by Flame photometer (DV710W). Atomic absorption spectrometer (Vario 6) was used to measure the concentration of zinc, copper, manganese (flame mode), arsenic (hydride mode) and calorimeter (HACH DR2800) for iron and fluorides; sulphates (DR/890) and nitrates were measured using spectrophotometer (SECOMAM UV Line 9400). The statistical method MPN (most probable number) was used for microbiological analysis (Rice et al. 2012). The measured values of samples were compared with the standard quality parameters of WHO and PSQCA for drinking water.

\section{Results and discussions}

Physico-chemical analyses of thermal springs are shown in Tables 1, 2, 3; some important physico-chemical parameters of Chutrun thermal Springs 1-4 have been graphically represented by Fig. 3a-d. The temperature of springs ranges from 40 to $42{ }^{\circ} \mathrm{C}$ during the month of March. The $\mathrm{pH}, \mathrm{EC}$, DO, alkalinity, turbidity, hardness and TDS values observed during analysis met the standard values given by WHO and PSQCA.

The concentration of cations, anions and their standard values are represented in Table 2 while Table 3 displays the statistical data (mean, median, mode, standard deviation) applied on chemical parameters of Table 1; it is worth mentioning that no standard value is set for bicarbonates. The concentration of ions was within the permissible limits, except fluorides which were 2-3 times higher
Table 1 Physico-chemical analyses of thermal springs

\begin{tabular}{llllllllll}
\hline parameters & $\begin{array}{l}\text { Temp } \\
\text { Air }\left({ }^{\circ} \mathrm{C}\right)\end{array}$ & $\begin{array}{l}\text { Temp } \\
\text { Water }\left({ }^{\circ} \mathrm{C}\right)\end{array}$ & $\begin{array}{l}\text { PH } \\
-\end{array}$ & $\begin{array}{l}\text { DO } \\
\text { ppm }\end{array}$ & $\begin{array}{l}\text { TDS } \\
\text { ppm }\end{array}$ & $\begin{array}{l}\text { Turbidity } \\
\text { NTU }\end{array}$ & $\begin{array}{l}\text { EC } \\
\mu \mathrm{S} / \mathrm{cm}\end{array}$ & $\begin{array}{l}\text { Hardness } \\
\text { ppm }\end{array}$ & $\begin{array}{l}\text { Alkalinity } \\
\text { ppm }\end{array}$ \\
\hline $\begin{array}{l}\text { Standard } \\
\begin{array}{l}\text { Porteous } \\
\text { et al. 2013) }\end{array}\end{array}$ & - & - & $6.5-8.5$ & 10 & 1000 & $<5$ & NGV & 500 & 600 \\
Spring1 & 15 & 42 & 7.25 & 6.64 & 306 & 2.2 & 510 & 280 & 252 \\
Spring2 & 15 & 41 & 7.35 & 6.7 & 308 & 1.75 & 514 & 278 & 252 \\
Spring3 & 14 & 40 & 7.8 & 3.7 & 310 & 1.62 & 516 & 285 & 260 \\
Spring4 & 14 & 42 & 7.21 & 3.1 & 300 & 2.42 & 500 & 280 & 250 \\
Application of & Statistics & & & & & & & & \\
parameters & Temp & Temp & PH & DO & TDS & Turbidity & EC & Hardness & Alkalinity \\
& Air $\left({ }^{\circ} \mathrm{C}\right)$ & Water $\left({ }^{\circ} \mathrm{C}\right)$ & - & ppm & ppm & NTU & & ppm & ppm \\
Mean & 14.5 & 41.25 & 7.40 & 5.035 & 306 & 1.997 & 510 & 280.75 & 253.5 \\
Median & 14.5 & 41.5 & 7.3 & 5.17 & 307 & 1.975 & 512 & 280 & 252 \\
Mode & 14,15 & 42 & - & - & - & - & - & 280 & 252 \\
Minimum & 14 & 40 & 7.21 & 3.1 & 300 & 1.62 & 500 & 278 & 250 \\
Maximum & 15 & 42 & 7.8 & 6.7 & 310 & 2.42 & 516 & 285 & 260 \\
SD & 0.5 & 0.83 & 0.235 & 1.65 & 3.74 & 0.325 & 6.16 & 2.58 & 3.84 \\
\hline
\end{tabular}

Table 2 Chemical analysis of thermal springs 1-4

\begin{tabular}{|c|c|c|c|c|c|c|c|c|c|c|c|c|c|c|c|}
\hline Ions & $\begin{array}{l}\mathrm{Na}^{+} \\
\text {ppm }\end{array}$ & $\begin{array}{l}\mathrm{K}^{+} \\
\mathrm{ppm}\end{array}$ & $\begin{array}{l}\mathrm{Ca}^{+2} \\
\mathrm{ppm}\end{array}$ & $\begin{array}{l}\mathrm{Mg}^{+2} \\
\mathrm{ppm}\end{array}$ & $\begin{array}{l}\mathrm{Zn}^{+2} \\
\mathrm{ppm}\end{array}$ & $\begin{array}{l}\mathrm{Cu}^{+2} \\
\mathrm{ppm}\end{array}$ & $\begin{array}{l}\text { Mn } \\
\text { ppm }\end{array}$ & $\begin{array}{l}\text { As } \\
\text { ppb }\end{array}$ & $\begin{array}{l}\mathrm{Fe} \\
\mathrm{ppm}\end{array}$ & $\begin{array}{l}\mathrm{HCO}_{3}^{-} \\
\mathrm{ppm}\end{array}$ & $\begin{array}{l}\mathrm{SO}_{4}{ }^{2-} \\
\mathrm{ppm}\end{array}$ & $\begin{array}{l}\mathrm{F}^{-} \\
\mathrm{ppm}\end{array}$ & $\begin{array}{l}\mathrm{CI}^{-} \\
\mathrm{ppm}\end{array}$ & $\begin{array}{l}\mathrm{CO}_{3}^{-} \\
\mathrm{ppm}\end{array}$ & $\begin{array}{l}\mathrm{NO}_{3}{ }^{-} \\
\mathrm{ppm}\end{array}$ \\
\hline $\begin{array}{l}\text { Std } \\
\text { (Porteous et al. } \\
\text { 2013) }\end{array}$ & 160 & 75 & 200 & 100 & 15 & 1 & 0.5 & 50 & 0.3 & NGV & 400 & 1.5 & 250 & NGV & 10 \\
\hline Spring1 & 12 & 3.9 & 80 & 20 & BDL & BDL & BDL & 0.54 & BDL & 260 & 85 & 3.6 & 9 & BDL & BDL \\
\hline Spring2 & 14 & 4 & 82 & 20 & BDL & BDL & BDL & 0.52 & BDL & 262 & 82 & 3.9 & 12 & BDL & BDL \\
\hline Spring3 & 18 & 4.1 & 82 & 20 & BDL & BDL & BDL & 0.61 & BDL & 282 & 80 & 3.5 & 10 & BDL & BDL \\
\hline Spring4 & 12 & 4.1 & 80 & 20 & BDL & BDL & BDL & 0.81 & BDL & 260 & 85 & 3.4 & 10 & BDL & BDL \\
\hline
\end{tabular}


Table 3 Application of statistics on chemical parameters of thermal springs $1-4$

\begin{tabular}{llllllllll}
\hline Statistics & $\mathrm{Na}^{+}$ & $\mathrm{K}^{+}$ & $\mathrm{Ca}^{+2}$ & $\mathrm{Mg}^{+2}$ & $\mathrm{As}$ & $\mathrm{HCO}_{3}{ }^{-}$ & $\mathrm{SO}_{4}{ }^{2-}$ & $\mathrm{F}^{-}$ & $\mathrm{CI}^{-}$ \\
\hline Mean & 14 & 4.025 & 81 & 20 & 0.620 & 266 & 83 & 3.6 & 10.25 \\
Median & 13 & 4.05 & 81 & 20 & 0.575 & 261 & 83.5 & 3.55 & 10 \\
Mode & 12 & 4.1 & 80,82 & 20 & - & 260 & 85 & - & 10 \\
Minimum & 12 & 3.9 & 80 & 20 & 0.52 & 260 & 80 & 3.4 & 9 \\
& 18 & 4.1 & 82 & 20 & 0.81 & 282 & 85 & 3.9 & 12 \\
SD & 2.45 & 0.083 & 1.58 & 0.00 & 0.115 & 9.27 & 2.12 & 0.187 & 1.09 \\
\hline
\end{tabular}

Table 4 Microbiological analysis

\begin{tabular}{llll}
\hline Samples & $\begin{array}{l}\text { Total Coliforms } \\
\text { (MPN/100 ml) }\end{array}$ & $\begin{array}{l}\text { Faecal } \\
\text { Coliforms }\end{array}$ & E.Coli \\
\hline $\begin{array}{l}\text { Standard (Porteous } \\
\text { et al. 2013) }\end{array}$ & Negative & Negative & Negative \\
Spring 1 & 6 & $-\mathrm{ve}$ & $-\mathrm{ve}$ \\
Spring 2 & 6 & $-\mathrm{ve}$ & $-\mathrm{ve}$ \\
Spring 3 & 6 & $-\mathrm{ve}$ & $-\mathrm{ve}$ \\
Spring 4 & 6 & $-\mathrm{ve}$ & $-\mathrm{ve}$ \\
\hline
\end{tabular}

in concentration than the standard range. Microbiological analyses are shown in Table 4.

Table 5 shows a comparision between various physicochemical parameters of some renowned thermal springs of the world.

Chemical composition of thermal springs has its own beneficial effects on human health; the water from these springs can increase metabolism, improve blood circulation, sooth muscles, accelerate healing and detoxify the body's lymphatic system soaking (Verhagen et al. 2004). The water from these thermal springs contains mineral contents within limits of drinking water standards laid by
WHO and PSQCA can be used for drinking purposes. The data shows that thermal springs of Chutrun (Shigar Valley) are suitable for bathing and body contact activities, but not fit for drinking due to high content of fluorides. There are two main benefit areas of bathing in hot mineral springs above $42^{\circ} \mathrm{C}$, temperature and minerals. Temperature of water causes the physical effects of body which improves oxygen flow in tissues, dilate the skin, increase flow rate of sedating substances and relaxes muscles (Dabbs 2009; Gutenbrunner et al. 2010).Chemical effects are due to the minerals, and other substances in the water are transferred to the skin and blood streams through the process of osmosis (Ghersetich and Lotti 1996). Then, utilized by body cells. Osmotic qualities, i.e., minerals concentration, the $\mathrm{pH}$ level and the minerals chemical forms in water affect the transdermal carrier effects of any mineral water. The temperature of Chutrun springs ranges from 40 to $42{ }^{\circ} \mathrm{C}$. Bathing in thermal springs containing calcium and magnesium is not only vital for growth, but also helps to maintain bones, cures for diseases of veins, neuritis, arthritis, bronchial infections and menstrual cramp (Altman 2000). It also promotes skin and converts blood sugar to energy (Mennuni et al. 2014). The Chutrun hot springs contain calcium(80-82 ppm)and

Table 5 Physico-chemical comparison between Chutrun hot springs and world's renowned thermal springs

\begin{tabular}{llllllll}
\hline Parameters & $\begin{array}{l}\text { Chutrun } \\
\text { (Pakistan) } \\
\text { (Shigar) }\end{array}$ & $\begin{array}{l}\text { Manghopir } \\
\text { (Pakistan) } \\
\text { (Javed et al. } \\
2009)\end{array}$ & $\begin{array}{l}\text { Selangor } \\
\text { (Malaysia) } \\
\text { (Hamzah et al. } \\
\text { 2013) }\end{array}$ & $\begin{array}{l}\text { Kusatsu (Japan) } \\
\text { (Kotake et al. } \\
1999)\end{array}$ & $\begin{array}{l}\text { Limpopo } \\
\text { (South Africa) } \\
\text { (Olivier et al. }\end{array}$ & $\begin{array}{l}\text { Arkanasas } \\
\text { (USA) } \\
\text { (Lund 1996) }\end{array}$ & $\begin{array}{l}\text { Ranong } \\
\text { (Thailand) } \\
\text { (Sudjaroen et al. } \\
\text { 2017) }\end{array}$ \\
\hline Temperature & $40-42$ & 47 & $36.1-67.90$ & $60-67$ & $26-67.5$ & $32-62$ & $61.5-65.3$ \\
PH & $7.21-7.8$ & $7.2-7.6$ & $7.14-8.98$ & 2 & $7.35-9.70$ & $4.52-7.70$ & $7.56-7.74$ \\
TDS (ppm) & $300-310$ & $2180-2188$ & $228-376 \mathrm{~s}$ & - & $104.7-1385$ & - & $210-230$ \\
Sodium (ppm) & $12-18$ & $544-555$ & $37-81.91$ & 53.70 & $10.5-156.3$ & 4 & $10.2-13.8$ \\
Potassium (ppm) & $3.8-4.1$ & $21-25$ & $1.7-56.81$ & 16 & $0.99-4.25$ & 1.5 & $150-189$ \\
Calcium (ppm) & $80-82$ & $80-84$ & $3.75-19.77$ & 72 & $1.31-13.73$ & 45 & $18.7-20.6$ \\
Magnesium (ppm) & 20 & 56 & $0.2-0.6$ & 39 & $0.00-27.6$ & 4.8 & $0.36-0.51$ \\
Chlorides (ppm) & $9.6-12$ & $584-599$ & $7.06-20.66$ & 343 & $19.4-168.97$ & 1.8 & $18.3-23.2$ \\
Fluorides (ppm) & $3.4-3.9$ & - & $4.0-4.2$ & 12 & $0.18-6.50$ & 0.2 & $8.12-0.89$ \\
Sulphates (ppm) & $80-85$ & $437-442$ & $0.15-1.51$ & 611 & $2.98-53.17$ & 8 & $8.1-12.1$ \\
Bicarbonates (ppm) & $260-282$ & $395-494$ & $60-108$ & - & - & $4.3-5.7$ \\
\hline
\end{tabular}


magnesium(20 ppm). It has been suggested, that sulphates are healthy digestion in terms of improvement of constipation symptoms, promote enzyme activity in redox processes and cellular respiration(Bothe et al. 2017). The sulphates in Chutrun hot springs are between 80 and $85 \mathrm{ppm}$. Researchers proved that bathing in bicarbonate water also prevents nervous system imbalances and cardiovascular diseases and helps to improve circulation to the body's extremities. European balneologists are also believed to use bicarbonate waters for bathing to cure mild atherosclerosis and hypertension (Bojadgieva et al. 2002; Mennuni et al. 2014). Chutrun hot springs contain 260-282 ppm bicarbonates. In geothermal hot springs, fluorides concentration above $1 \mathrm{mg} / \mathrm{Lit}$ have the medicinal value. (Dojlido and Best 1993). Fluorides contents in Chutrun hot springs are 3.4 to $3.9 \mathrm{ppm}$. It protects and prevent tooth decay, bone mineralization and development. (Ambarkova et al. 2012; Quattrini et al. 2016). For drinking purpose, the values of Fluorides in all Chutrun thermal springs found above the permissible limit given by WHO and PCSQA. Due to high-concentration, of fluorides above, $1.5 \mathrm{mg} / \mathrm{L}$ waters of these thermal springs are not recommended for portable use. The high intake of fluoridated water may have carcinogenic effects and some toxic effects from dental fluorosis to skeletal fluorosis (Wang et al. 2004). Chutrun hot springs contain 12-18 ppm of potassium, 12-18 ppm of sodium and between 9 and $12 \mathrm{ppm}$ of chlorides which are found in low amount. But according to medical balneotherapists, small amounts of therapeutic minerals absorbed into the body through skin also have a significant therapeutic value (Javed et al. 2009; ur Rahman and Bilal 2017). The other analysed trace elements, i.e., zinc, copper, manganese and iron concentrations are below detection limits except arsenic $(0.5-0.81 \mathrm{ppb})$ which is a toxic element, present in less amount. Carbonates were not detected due to weak alkaline nature of Chutrun hot springs. According to WHO and PSQCA, total coliforms, faecal, coliforms and $E$. Coli, should be negative for, drinking water. Faecal, Coliforms and E. Coli, both are found negative which indicated the absence of contamination caused by fertilizers and other organic wastes but positive for total coliforms having same values of all samples which may be due to environmental bacteria and non-protective measures during sampling.

Similar studies on world's renowned thermal springs, i.e., Ikogosi (Nigeria), Selangor (Malaysia), Arkanasas (USA), Southern/Northern part of Limpopo (South Africa), Kusatsu (Japan), Ranong (Thailand), Shrgalijuut (Mongolia) and Monghopir (Pakistan) have shown the presence of 4.3-494 mg/L bicarbonates, $0.15-442 \mathrm{mg} / \mathrm{L}$ sulphates, $0.00-982.62 \mathrm{mg} / \mathrm{L}$ chlorides, $0.12-12 \mathrm{mg} / \mathrm{L}$ fluorides, $0.00-56 \mathrm{mg} / \mathrm{L}$ magnesium, $2.06-84 \mathrm{mg} / \mathrm{L}$ calcium, 0.67-189 mg/L potassium and 0.67-621.99 mg/L sodium; they possessed TDS value of $104.74-2188 \mathrm{mg} / \mathrm{L}$, $\mathrm{pH} 2.0-9.7$ and the temperature of $26.0-90.50{ }^{\circ} \mathrm{C}$ (Hussain 2020). Recent studies have suggested the effectiveness of Nigerian thermal springs for the treatment of chronic health conditions and muscoskeletal disorders (Olayinka 2020).

There are common practices of natural therapy modalities such as balneotherapy and thermal therapy for the treatment of pains and chronic aches all over the world. Studies on thermal springs of Nepal have also reported some cases of outbreaks of infection from common spring baths so it is necessary to provide awareness regarding safety of the people seeking treatment. (Vaidya and Nakarmi 2020).

\section{Conclusions}

Groundwater containing minerals and temperature above $40{ }^{\circ} \mathrm{C}$ is called hot mineral spring. All four thermal springs in Chutrun (Shigar Valley) are classified as Hot springs with weak alkaline nature having almost same amount of physical and chemical parameters due to same geological and environmental conditions around springs which found suitable for bathing and unsuitable for potable use. Physical effects being result of water temperature, improves oxygen flow in tissues, dilate the skin, increase flow rate of sedating substances and relaxes muscles. The major ions present are responsible for the therapeutic potentials of these hot springs are calcium, magnesium, potassium, fluorides and bicarbonates which are found curative for acid base balance in blood, bone mineralization, diseases of veins, arthritis, cardiovascular diseases and positive effect on digestive tract. Absence of faecal coliforms and $E$. coli indicated contamination free environment of thermal springs. Chutrun hot springs are found fit for Balneotherapy.

Acknowledgements $\mathrm{SH}$ is thankful to Pakistan Council for Research in Water Resources (PCRWR), Islamabad for facilitating NF to use laboratory and Instruments during the whole research work. Moreover, we declare that this research did not receive any specific funding.

Author contributions NF is MPhil Student, Performed experimental work, Manuscript writing; $\mathrm{SH}$ is Supervisor in whole work; FF is Assistance in analysis of the samples; IB is Manuscript writing; MN is Literature Survey.

Funding We declare that this research did not receive any specific funding. 
Availability of data and materials All the analytical data are provided in manuscript. For any further requirement, corresponding author is available.

\section{Compliance with ethical standards}

Conflict of interest It is hereby verified that there is no conflict of interest between the authors.

Human or animals rights The current research does not involve any direct experiments on human beings. The experiments were performed only on physico-chemical analysis of water of thermal springs. The therapeutic potential of this water has been discussed only from reported literature which has been cited.

Informed consent No direct experiments were performed on human beings during this research. The research involves only physico-chemical analysis of thermal springs.

Open Access This article is licensed under a Creative Commons Attribution 4.0 International License, which permits use, sharing, adaptation, distribution and reproduction in any medium or format, as long as you give appropriate credit to the original author(s) and the source, provide a link to the Creative Commons licence, and indicate if changes were made. The images or other third party material in this article are included in the article's Creative Commons licence, unless indicated otherwise in a credit line to the material. If material is not included in the article's Creative Commons licence and your intended use is not permitted by statutory regulation or exceeds the permitted use, you will need to obtain permission directly from the copyright holder. To view a copy of this licence, visit http://creativecommons.org/licenses/by/4.0/.

\section{References}

Agheem MH, Shah MT, Khan TU (2004) Gems and gem-bearing pegmatites of the Shigsr Valley Skardu Northern Pakistan. Geol Bull Univ Peshawar 37:167-178

Agheem MH, Shah MT, Khan T, Laghari A, Dars H (2011) Field features and petrography used as indicators for the classification of Shigar valley pegmatites, Gilgit-Baltistan region of Pakistan. Himal J Earth Sci Univ Peshawar 44(2):1-7

Altman N (2000) Healing springs: the ultimate guide to taking the waters. Inner Traditions/Bear \& Co., Rochester

Ambarkova V, Sijakova-Ivanova T, Zabokova-Bilbilova E (2012) Preliminary investigations of fluoride content in the water of three main lakes in the Republic of Macedonia. Geologica Macedonica 26(1):81-85

Bisht SS, Das NN, Tripathy N (2011) Indian hot-water springs: a bird's eye view. J Ener Environ Carbon Credits 1:1-15

Blauwet D, Smith B, Smith C (1997) A guide to the mineral localities of the Northern Areas. Pak Mineral Record 28(3):183

Bojadgieva K, Dipchikova S, Benderev A, Koseva J (2002) Thermal waters and balneology in Bulgaria. The online version of this article can be found at: http://geoheat.oit.edu/bulletin/bull23-1/ art5.pdf.

Bothe G, Coh A, Auinger A (2017) Efficacy and safety of a natural mineral water rich in magnesium and sulphate for bowel function: a double-blind, randomized, placebo-controlled study. Eur J Nutr 56(2):491-499

Dabbs GR (2009) Health and nutrition at prehistoric Point Hope, Alaska: application and critique of the Western Hemisphere Health Index. University of Arkansas, Fayetteville
Dojlido J, Best GA (1993) Chemistry of water and water pollution. Ellis Horwood Limited, Chichester

Ghersetich I, Lotti TM (1996) Immunologic aspects: immunology of mineral water spas. Clin Dermatol 14(6):563-566

Gutenbrunner C, Bender T, Cantista P, Karagülle Z (2010) A proposal for a worldwide definition of health resort medicine, balneology, medical hydrology and climatology. Int J Biometeorol 54(5):495-507

Hamzah Z, Rani NA, Saat A, Wood AK (2013) Determination of hot springs physico-chemical water quality potentially use for balneotherapy. Malaysia J Anal Sci 17(3):436-444

Hussain S (2020) Physicochemical nature and therapeutic potential of thermal springs: an overview. Pak J Anal Environ Chem 21(1):01-09

Javed A, Iqbal J, Asghar U, Khan FA, Munshi AB, Sddiqui I (2009) A study to evaluate therapeutic properties of minerals of Manghopir hot spring. Karachi J Chem Soc Pak 31(3):397

Kotake S, Udagawa N, Takahashi N, Matsuzaki K, Itoh K, Ishiyama S, Saito S, Inoue K, Kamatani N, Gillespie MT (1999) IL-17 in synovial fluids from patients with rheumatoid arthritis is a potent stimulator of osteoclastogenesis. J Clin Invest 103(9):1345-1352

Lele OH, Deshmukh PV (2016) Isolation and characterization of thermophilic Bacillus sp. with extracellular enzymatic activities from hot spring of Ganeshpuri Maharashtra India. Int J Appl Res Technol 2(5):427-430

Liang J, Kang D, Wang Y, Yu Y, Fan J, Takashi E (2015) Carbonate ion-enriched hot spring water promotes skin wound healing in nude rats. PLoS ONE 10(2):e0117106

Lopez HW, Leenhardt F, Coudray C, Remesy C (2002) Minerals and phytic acid interactions: is it a real problem for human nutrition? Int J Food Sci Technol 37(7):727-739

Luime J, Koes B, Hendriksen I, Burdorf A, Verhagen A, Miedema H, Verhaar J (2004) Prevalence and incidence of shoulder pain in the general population; a systematic review. Scand J Rheumatol 33(2):73-81

Lund JW (1996) Balneological use of thermal and mineral waters in the USA. Geothermics 25(1):103-147

Mennuni G, Petraccia L, Fontana M, Nocchi S, Stortini E, Romoli M, Esposito E, Priori F, Grassi M, Geraci A (2014) The therapeutic activity of sulphate-bicarbonate-calcium-magnesiac mineral water in the functional disorders of the biliary tract. La Clinica terapeutica 165(5): e346-352

Mohanty S, Mahanty A, Yadav RP, Purohit GK, Mohanty BN, Mohanty BP (2014) The Atri hot spring in Odisha-a natural ecosystem for global warming research. Int J Geol Earth Environ Sci 4(1):85-90

Olayinka O (2020) Balneotherapy/Spa therapy: potential of Nigerian thermal hot spring waters for Musculoskeletal disorders and chronic health conditions. Int J Adv Res Publ 4(3):95-100

Olivier J, Van Niekerk H, Van der Walt I (2008) Physical and chemical characteristics of thermal springs in the Waterberg area in Limpopo Province. South Africa Water SA 34(2):163-174

Olivier J, Venter J, Jonker C (2011) Thermal and chemical characteristics of hot water springs in the northern part of the Limpopo Province, South Africa. Water Sa 37(4):427-436

Porteous N, Sun Y, Dang S, Schoolfield J (2013) A comparison of 2 laboratory methods to test dental unit waterline water quality. Diagn Microbiol Infect Dis 77(3):206-208

Quattrini S, Pampaloni B, Brandi ML (2016) Natural mineral waters: chemical characteristics and health effects. Clin Cases Mineral Bone Metab 13(3):173

Reyes JM, Soriano AO, Jaramillo ME, Romero IV (2015) Physicalchemical and therapeutic properties of hot springs and hydrothermal waters. Int J Res Innov Earth Sci 2(1):10-12

Rice EW, Baird RB, Eaton AD, Clesceri LS (2012) Standard methods for the examination of water and wastewater. American Public Health Association, Washington, DC 
Sudjaroen Y, Thongkao K, Suwannahong K (2017) Characteristics of mineral water from nature hot springs in Ranong Province, Thailand. Ann Trop Med Public Health 10(2):366

ur Rahman S, Bilal S (2017) Insights into the factors responsible for curative effects of Aab-E-Shifa Spring Hasan Abdal (Pakistan). Appl Water Sci 7(4):1741-1746

Vaidya B, Nakarmi S (2020) A qualitative study of patients' beliefs and perception on medicinal properties of natural hot spring bath for Musculoskeletal Problems. J Environ Public Health 2020. https ://doi.org/10.1155/2020/3694627

Verhagen AP, Bierma-Zeinstra SMA, Boers M, Cardoso JR, Lambeck J, de Bie R, de Vet HCW (2004) Balneotherapy for rheumatoid arthritis. Cochrane Database Syst Rev. https://doi. org/10.1002/14651858.CD000518

Wang B, Zheng B, Zhai C, Yu G, Liu X (2004) Relationship between fluorine in drinking water and dental health of residents in some large cities in China. Environ Int 30(8):1067-1073

Publisher's Note Springer Nature remains neutral with regard to jurisdictional claims in published maps and institutional affiliations. 